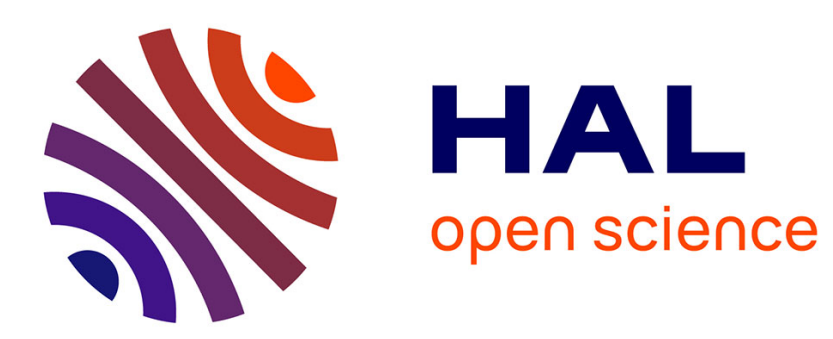

\title{
Increase in Home Bias and the Eurozone Sovereign Debt Crisis
}

\author{
Camille Cornand, Pauline Gandré, Céline Gimet
}

\section{To cite this version:}

Camille Cornand, Pauline Gandré, Céline Gimet. Increase in Home Bias and the Eurozone Sovereign Debt Crisis. 2014. halshs-01015475v1

HAL Id: halshs-01015475

\section{https://shs.hal.science/halshs-01015475v1}

Preprint submitted on 26 Jun 2014 (v1), last revised 16 Sep 2015 (v3)

HAL is a multi-disciplinary open access archive for the deposit and dissemination of scientific research documents, whether they are published or not. The documents may come from teaching and research institutions in France or abroad, or from public or private research centers.
L'archive ouverte pluridisciplinaire HAL, est destinée au dépôt et à la diffusion de documents scientifiques de niveau recherche, publiés ou non, émanant des établissements d'enseignement et de recherche français ou étrangers, des laboratoires publics ou privés. 
Increase in Home Bias and the Eurozone Sovereign Debt Crisis

Camille Cornand, Pauline Gandré, Céline Gimet 


\section{GATE Groupe d'Analyse et de Théorie Économique Lyon-St Étienne}

93, chemin des Mouilles 69130 Ecully - France

Tel. +33 (0)4 72866060

Fax $+33(0) 472866090$

6, rue Basse des Rives 42023 Saint-Etienne cedex 02 - France

Tel. +33(0)4 77421960

Fax. +33 (0)4 77421950

Messagerie électronique / Email : gate@gate.cnrs.fr

Téléchargement / Download : http://www.gate.cnrs.fr - Publications / Working Papers 


\title{
Increase in Home Bias and the Eurozone Sovereign Debt Crisis *
}

\author{
Camille Cornand ${ }^{\dagger} \quad$ Pauline Gandré ${ }^{\ddagger} \quad$ Céline Gimet $^{\S}$
}

May, 2014

\begin{abstract}
One of the most striking consequences of the recent episode of sovereign debt market stress in the Eurozone has been the increase in the share of public debt held by the domestic sector in fragile economies. First, we identify the shocks that explain most of the variation in this share in an S-VAR model on a sample of 7 Eurozone countries between 2007 and 2012. Home bias in sovereign debt responds positively to fundamentals and expectations shocks but we find no evidence that the increase in home bias is destabilizing per se. Second, we theoretically model the impact of the previous shocks in a second-generation model of crisis with endogenous home bias in sovereign debt. We derive conditions under which a higher home bias is associated with a change in the government's decision. Finally, we discuss which case of the model best applies to the distinct countries in our sample during the recent sovereign debt crisis in the Eurozone.
\end{abstract}

JEL classification: E4, E5, F3, G15.

Keywords: Eurozone, Sovereign debt crises, Home bias, Bayesian panel S-VAR, Second-generation model.

*We thank Stephan Sauer, Andrea Bonilla Bolaños, Aurélien Eyquem, Nicolas Houy, as well as participants at the $11^{\text {th }}$ Infiniti Conference, the $11^{\text {th }}$ Doctoriales Macrofi, the $2^{\text {nd }}$ Finandebt Conference and the $63^{r d}$ AFSE Conference, in particular our discussants Livia Chitu and Matthieu Charpe, for helpful comments and discussions.

${ }^{\dagger}$ cornand@gate.cnrs.fr, Université de Lyon, Lyon, F-69007, France and CNRS, GATE Lyon Saint-Etienne, Ecully, F-69130, France.

${ }^{\ddagger}$ pauline.gandre@ens-lyon.fr, Ecole Normale Supérieure de Lyon, Lyon, F-69007, France and GATE Lyon Saint-Etienne, Ecully, F-69130, France.

${ }^{\S}$ celine.gimet@sciencespo-aix.fr, Institute of Political Studies, CHERPA, EA 4261, Aixen-Provence, France and GATE Lyon Saint-Etienne, Ecully, F-69130, France. 


\section{Introduction}

One of the most striking and seemingly surprising consequences of the recent episode of sovereign debt market stress in the Eurozone has been the increase in the share of public debt held by the domestic sector in fragile economies (see Brutti and Saure (2013), Van Riet (2014), Arslanalp and Tsuda (2012) and Merler and Pisani-Ferry (2012)). Despite a deep period of stress on the public debt market of the peripheral Eurozone countries, residents have significantly increased their purchases of domestic sovereign bonds, both in volume and in proportion. By the end of March 2012, the share of public debt held by the domestic sector was above $40 \%$ in all GIIPS countries, and close to $60 \%$ in Italy and 70\% in Spain (Andritzky (2012)).

This paper argues that the recent increase in home bias in sovereign debt ${ }^{1}$ in the Eurozone was produced by rising incentives to buy the debt of domestic investors relative to foreigners following an increase in the expected probability of default. The paper empirically identifies the macroeconomic factors that can prompt home bias in sovereign debt to increase and theoretically determines the consequences on the government's strategic decision to default in the Euro area. ${ }^{2}$

Using a Bayesian Structural VAR estimation that relies on a sample of 7 Eurozone countries between 2007Q1 and 2012Q1, we go beyond the stylized facts by first determining the causes and direct consequences of the recent increase in home bias in the Eurozone. We show that shocks on fundamentals and on country-specific expectations are the two main contributors to increased home bias in our empirical model. In addition, we find no evidence that an increase in home bias leads to

\footnotetext{
${ }^{1}$ As Acharya et al. (2012), we consider that 'Home bias in government debt is total home sovereign debt as a share of total sovereign debt'(p. 54). Our definition may differ from the commonly accepted definition, according to which home bias is the propensity of investors to make financial investments in their home countries rather than in foreign markets (home bias in portfolios).

${ }^{2}$ The impact of an increase in home bias on other economic outcomes, such as banking risk, is beyond the scope of this paper.
} 
a decrease in the growth rate or to an increase in the spreads in our sample.

We then propose a 2-period second-generation model of sovereign debt crises in a monetary union, the assumptions of which are supported by our empirical results. The model illustrates the mechanism through which home bias affects the government's decisions regarding default by incorporating both the plausible causes and direct consequences of an increase in home bias identified in our empirical tests. We then derive the consequences of an increase in home bias on the government's fiscal decision.

We model the decision of an optimizing government attempting to minimize the economic and political costs of its fiscal policy. The government's strategic decision is affected both by the cost of taxation and the cost of default, which depend on home bias. ${ }^{3}$ Therefore, multiple equilibria conditional on expectations and home bias can then arise for a given fundamental.

Differently to most second-generation models of crises, the optimal decision of investors arises endogenously in the model (see Blot et al. (2014) for another example). Our empirical results then allow us to focus on two distinct exogenous sources of variation in the model. We show how a higher fiscal fundamental and more pessimistic expectations shift the market equilibrium towards higher interest rate and home bias. We derive a straightforward sufficient condition such that this variation in investors' decisions leads to a switch in the government's decision from a non-default to a default equilibrium. If the increase in home bias has any effect per se, it is to make the switch in equilibrium less likely. The switch is thus conditional on the relative extent of the source of vulnerability triggering the increase in home bias and of the stabilizing impact of home bias. The model succeeds in replicating the recent stylized facts of the Eurozone. Finally, we iden-

\footnotetext{
${ }^{3}$ The foreign cost of default was identified in the theoretical literature long ago (see Eaton and Gersovitz (1981) for a seminal work). Even though an empirical consensus relativizing this cost existed (see Panizza et al. (2009) for a survey), recent work has provided empirical evidence of significant reputation costs and trade sanctions (Cruces and Trebesch (2013), Borenzstein and Panizza (2009)).
} 
tify which case of the model best applies to the distinct countries of our sample. To the best of our knowledge, no other work empirically investigates the reasons for the recent increase in home bias in sovereign debt in the Eurozone and gathers in a theoretical model the several effects of home bias on the government's fiscal decision, - identified in prior studies - to derive simple implications.

Our paper relates to Gros (2012) and De Grauwe (2011), who - in line with the literature on second-generation speculative attack models (Obstfeld (1994), Obstfeld (1996)) and its application to sovereign debt crisis ${ }^{4}$ - analyze the recent European debt crisis as a self-fulfilling, speculative dynamic. Like ours, these papers show that crises can be triggered by creditors' sudden pessimism, leading them to refuse to buy debt or to demand high interest rates. However, none of these papers directly focus on home bias. Regarding home bias in sovereign debt or in banks' sovereign bonds portfolios, recent literature has focused on its impact on the transmission of sovereign risk to the banking sector (Acharya et al. (2014)) rather than on its direct impact on default decisions. Broner et al. (2014), Mengus (2013) and Gennaioli et al. (2014) are recent exceptions. Broner et al. (2014) argue that creditors' discrimination can favor purchases of sovereign debt by domestic investors. Because of financial frictions, this can lead to crowding-out effects by disrupting domestic productive investment, and lower growth. In addition, we cannot find empirical confirmation of a negative effect of home bias on growth in our sample once other main variables are controlled for and do not include it in the model. Similarly to us, Mengus (2013) argues that home bias increases the government's internal cost of default. ${ }^{5}$ This cost arises endogenously in Gennaioli

\footnotetext{
${ }^{4}$ First models of self-fulfilling sovereign debt crises include Calvo (1988) and Cole and Kehoe (2000). This category of models was recently applied to the current crisis (Corsetti and Dedola (2011), Aguiar et al. (2014) and Lorenzoni and Werning (2013)). De Grauwe (2011), De Grauwe and Ji (2013), and Bruneau et al. (2012), among others, have shown the empirical relevance of the theory of self-fulfilling prophecies in the context of the recent Eurozone debt crisis.

${ }^{5}$ In his model, home bias results from the bailout of domestic investors, whereas in our model, home bias arises more generally from the distinct additional costs and benefits (in-
} 
et al. (2014), who also provide empirical evidence showing that higher home bias in sovereign debt portfolios increases the cost of default. Nevertheless, none of these papers address the role of home bias in the government's decision through the cost of taxation and the external cost of default.

Empirically, Battistini et al. (2013) study the determinants of home bias seen as a measure of market segmentation in the Eurozone. The authors focus on home bias in banks' portfolios - defined as the domestic sovereign debt holdings of the banks in one country scaled by their total assets- whereas we address a general measure of home bias in sovereign debt. Relying on a sample of advanced economies, Andritzky (2012) shows that the share of public debt held abroad responds positively to a negative shock on yields in the Euro area thanks to a panel VAR model. The author does not find proof of a reverse causality effect, which is consistent with our results. Whereas Andritzky focuses on disentangling the causal relationship between yields on sovereign bonds and the share of debt held by foreigners, we analyze the impact of fundamental shocks and world risk aversion shocks on the dynamics of home bias.

The next section presents some stylized facts about home bias in the Eurozone and performs econometric analyses that are useful for selecting the main assumptions of our theoretical model. Section 3 develops the model of self-fulfilling debt crisis. Section 4 discusses which case of the model best applies to the distinct countries in our sample. Section 5 concludes the paper.

\section{Home bias in the Eurozone}

In the following section, we identify recent features in the origin and evolution of home bias that are specific to the Eurozone. We then analyze the shocks that creasing in the expected probability of default) of buying domestic public debt for both groups. 
explain most of the variation in home bias using a panel S-VAR model and provide some results on the impact of home bias on the other variables.

\subsection{Evolution and origin of home bias}

Four main stylized facts about home bias can be identified in the Eurozone as shown on Figure $1 .^{6}$
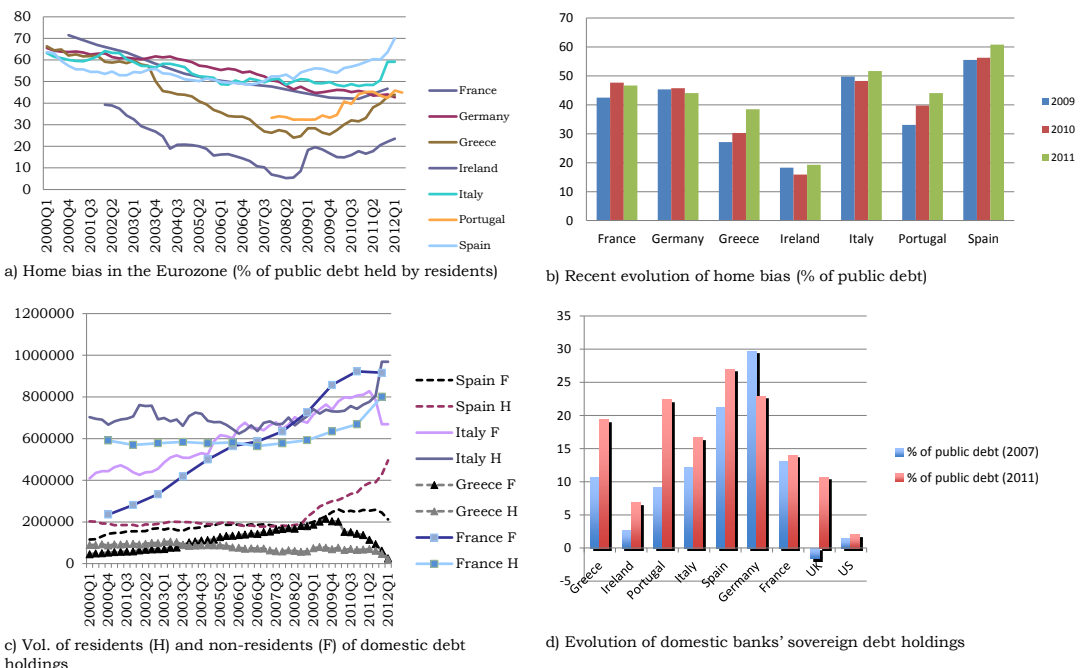

b) Recent evolution of home bias (\% of public debt)

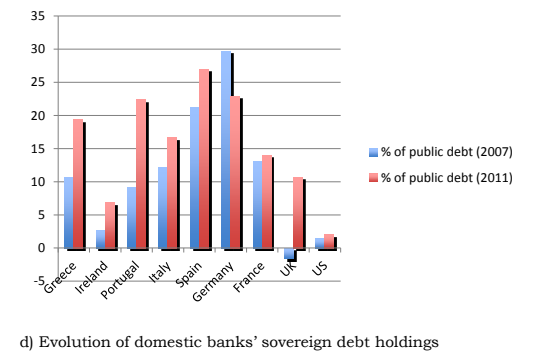

Figure 1: Evolution and origin of home bias - Sources: Andritzky (2012) (a, b, c); Merler and Pisani-Ferry (2012) (d).

First, there was a recent increase in home bias during the Euro area sovereign debt

\footnotetext{
${ }^{6}$ Notice that the stylized facts that we emphasize here deal with variation in home bias and not with level home bias in a particular context of stress on the sovereign debt market in a monetary union. Consequently, we focus on the causes and consequences of a shortterm increase in home bias in this particular context. Therefore, the case we investigate is different to that of Japan, where home bias in public debt is known to be high $(90 \%$ in the first quarter of 2012, according to Andritzky's database) but stable. Consequently, the high Japanese home bias does not seem to be the short-term result of destabilizing macroeconomic shocks.
} 
crisis. The proportion of domestic holding of public debt significantly decreased since the creation of the Eurozone in 1999, revealing a deepening of European financial markets integration (Figure 1 a). Nonetheless, home bias began increasing in most Eurozone countries except Germany, in the aftermath of the global financial crisis and the consecutive debt crisis in the Eurozone. ${ }^{7}$ The increase in home bias began at the end of 2008 or the beginning of 2009 in peripheral Eurozone countries.

Second, the increase in home bias seems to be higher in the most fragile Eurozone economies, such as Greece, Italy, Spain, Ireland and Portugal (Figure 1 b).

Third, the increase in home bias has distinct features across European countries. In Italy, Spain and Ireland, the increase is due to a decrease in the volume of public debt held by non-residents simultaneous to an increase in the volume of public debt held by residents. In Greece, it is due to a decrease in both volumes (Figure $1 \mathrm{c})$. In France, the increase is due to the increasing volume of public debt held by residents, which has recently been faster than the increase in the volume of public debt held by non-residents.

Fourth, domestic public debt holding in the Eurozone is mainly concentrated in the banking and financial sectors, which deepens the intertwining between sovereign debt risk and banking sector risk (Acharya et al. (2014)). More notably, this intertwining has recently increased, with a stronger exposure of domestic banks to domestic sovereign debt (Figure $1 \mathrm{~d}$ ). ${ }^{8}$ This feature is clearly more significant in Europe compared with the UK and the US.

We now conduct empirical tests to provide some elements on the factors that may

\footnotetext{
${ }^{7}$ In the case of France, the increase in home bias is more recent than in other countries. Therefore, it is not visible in Figure $1 \mathrm{~b}$ but it is visible in Figure $1 \mathrm{a}$.

${ }^{8}$ The argument according to which banks have increased their general exposure to sovereign bonds following the Basel II regulation is not sufficient to explain the evolution observed in the data. Indeed, home bias in banks' sovereign bonds portfolio has significantly increased (see Battistini et al. (2013)), meaning that banks have increased their exposure to domestic sovereign bonds more than to foreign sovereign bonds.
} 
have triggered the increase in home bias and to find empirical evidence on the effect of the increase in home bias.

\subsection{Empirical Tests}

We rely on a quarterly panel sample of 7 Eurozone economies for which data on home bias in public debt is available, and which faced a significant increase in home bias (Greece, Ireland, Italy, Portugal, Spain), a more recent increase in home bias (France) or a decrease in home bias (Germany), between 2007:Q1 and 2012:Q1.9

The period prior to the outbreak of the 2007 global financial crisis is likely to display structural differences, whereas the following period may present inconsistent features following the partial Greek default. On the one hand, the starting point of our analysis coincides with the beginning of a turmoil period on financial markets characterized by much higher volatility in both advanced and emerging economies (Dooley and Hutchinson (2009)). On the other hand, the first quarter of 2012 represents the climax of the European sovereign debt crisis, with the Greek partial default and the consecutive activation of sovereign CDS on Greek debt.

Our choice of a panel data analysis is motivated by the fact that we want to draw a general conclusion for the whole Eurozone on the factors behind the common increase in home bias for most of the countries in the sample. We want to establish a general relationship between our variables of interest that would be relevant for the entire sample once individual heterogeneity is controlled for and that would allow for making more than country-specific forecasts on the impact of an increase in home bias.

\footnotetext{
${ }^{9}$ An interesting additional test would be to extend our sample period so that it starts with the beginning of the monetary union and to test for non-linearities. Nevertheless, because many data on home bias are missing before 2007 and would require frequent use of interpolation methods, we focus on the period 2007-2012. In addition, for this last period, we can check the robustness of our results by substituting the spread on bonds by the CDS premium spread, for which data are available only for the end of the period.
} 
The increase in home bias observed in most of the sample is sudden and coincides with some lag with the start of the stress period on the Eurozone debt markets (the increase in home bias begins a bit before). Therefore, it is consistent to interpret the increase in home bias as the consequence of an unexpected shock. This is why we investigate the impact of different shocks on the dynamics of home bias to identify the most explanatory ones, relying on a Structural VAR model.

The empirical model Distinct arguments support our empirical strategy. First, the S-VAR model enables us to perform an analysis of unexpected shocks. Second, our identification strategy allows us to interpret the shocks in economic terms, which would be impossible in a simple VAR model. Third, an S-VAR model makes it possible to analyze bi-directional causalities without facing endogeneity issues. Therefore, we can identify both the shocks on the variables that prompt home bias to respond positively and the impact of a shock on home bias on the other variables in the model.

Our S-VAR model includes 5 variables. In a first step, we identify the main sources of variation in home bias (hb). There are two types of sources of variation: fundamental shocks and expectations shocks.

The fundamental fiscal shock that we consider is a shock on the fiscal space variable which is the ratio of debt on total tax revenues (fs). Aizenman and Jinjarak (2013) show that this variable accounts for a significant portion of the market pricing of risk. In addition, we include two different expectations variables. First, we consider global, non-European-specific expectations, as proxied by the VIX (vix), which represents the near term volatility conveyed by stock index option prices (S\&P 500 index) and is used as a proxy for global risk aversion (Favero and Giavazzi (2008), among others, have shown that the Eurozone economies are deeply affected by global conditions). Second, we consider country-specific expectations of sovereign default. We proxy a country-specific expectations shock with a shock 
on the spread on 10-year yields on sovereign bonds (spread), with the fundamental variables remaining constant. This shock is calculated as the difference between the US yield and the German yield for Germany and as the difference between the German yield and each country yield for all other countries in the sample.

Additionally, we include the quarter-on-quarter change of seasonally adjusted GDP at constant prices (gdp) as a further fundamental control and for assessing whether an increase in home bias can impact the GDP, everything else being equal in the S-VAR.

Data on home bias, defined as the share of total sovereign debt held by domestic investors, was extracted from the new database of Andritzky (2012). Data on VIX comes from CBOE and data on 10-year government bonds yields, seasonally adjusted quarter-on-quarter change in real GDP and the fiscal space variables were extracted from the Eurostat and OECD databases. ${ }^{10}$

The reduced form of the panel vector auto-regression model VAR(q) is:

$$
Y_{i, t}=\sum_{i=1}^{n} \sum_{j=1}^{q} A_{j} Y_{i, t-j}+e_{i, t}
$$

where $q$ is the number of lags, $n$ the number of countries, $Y_{i, t}$ the vector of endogenous variables, $Y_{i, t-j}$ the $n \times 1$ vector of lagged variables for each $i, A_{j}$ the $n \times n$ parameter matrix, and $e_{i, t}$ the vector of errors with $e_{i, t}=b_{i}+b_{t}+b_{i, t}$ where $b_{i}$ is the individual fixed effect, $b_{t}$ the time fixed effect and $b_{i, t}$ the disturbance term which variance-covariance matrix has no restrictions, that is $E\left(b_{i, t}, b_{i, t}^{T}\right)=\Omega$ and $E\left(b_{i, t}\right)=0$. Relying on the Wold theorem, the canonical VAR model can be reverted. Thus, we can rewrite the process in moving average infinite structural form:

$$
Y_{i, t}=\sum_{j=1}^{n} \sum_{k=0}^{\infty} C_{k} e_{i, t-k}=C(L) e_{i, t},
$$

\footnotetext{
${ }^{10}$ We relied on interpolation methods for missing data on home bias for France and Portugal.
} 
where $e_{t}$ represents the vector of canonical innovations and $\mathrm{L}$ is the lag operator. This allows to derive the impulse response functions and the forecast error variance decomposition. The structural Moving Average representation is then:

$$
Y_{i, t}=\sum_{j=1}^{n} \sum_{k=0}^{\infty} \Theta_{k} \varepsilon_{i, t-k}=\Theta(L) \varepsilon_{i, t}
$$

where $\varepsilon_{i, t}=d_{i}+d_{t}+d_{i, t}$ and $b_{i, t}=P d_{i, t}$ (Beetsma et al. (2006), Canova and Ciccarelli (2013)).

$\mathrm{P}$ is a $n \times n$ invertible matrix which needs to be estimated in order to identify the structural shocks. The short-run constraints are imposed directly on $P$ and consist in setting some elements of the matrix to zero. The $\Theta_{k}$ matrix represents the response functions of $Y_{i, t}$ to structural shocks $d_{i t}$. These latter are assumed to be uncorrelated and to have a unit variance: $E\left(d_{i, t}, d_{i, t}^{T}\right)=I_{n}$. With $\Omega$ the variancecovariance matrix of the canonical innovations $b_{i, t}$, we have:

$E\left(b_{i, t}, b_{i, t}^{T}\right)=P E\left(d_{i, t}, d_{i, t}^{T}\right) P^{T}=P P^{T}=\Omega$.

For the estimation of our panel S-VAR, we rely on Bayesian inference with the standard priors of Sims and Zha (1998) in order to identify the $P$ matrix. The advantages of such an estimation strategy are threefold. First, the priors are not flat, they enable to incorporate economic theory. Second, they do not imply any restrictions on the conditional mean of lagged variable coefficients. Nevertheless, beliefs about lagged variable coefficients are restricted to be Gaussian and uncorrelated across equations conditional on contemporaneous variable coefficients. However, they are allowed to be correlated differently in different equations. Third, Bayesian inference is not affected by the presence of unit roots and cointegration. Consequently, we can introduce the variables in levels rather than in first differences. This enables better interpretation regarding significance and sign of the results (Sims (1988), Sims and Uhlig (1991)). 


$$
\text { With } Y=\left(\begin{array}{c}
v i x \\
h b \\
\text { spread } \\
f s \\
g d p
\end{array}\right) \text { the vector of endogenous variables, and } \epsilon_{t}=\left(\begin{array}{c}
\varepsilon_{\text {ext }} \\
\varepsilon_{h b} \\
\varepsilon_{\text {spread }} \\
\varepsilon_{f s} \\
\varepsilon_{r s}
\end{array}\right)
$$

the vector of structural shocks, where $\varepsilon_{\text {ext }}$ represents the global financial shock and $\varepsilon_{h b}, \varepsilon_{\text {spread }}, \varepsilon_{f s}$ and $\varepsilon_{r s}$ are respectively the home bias shock, the spread shock, the fiscal space shock and the real supply shock.

The short-run restrictions We only impose short-run restrictions. Our objective is to identify the $n^{2}$ elements of the $P$ matrix. The $\Omega$ matrix is symmetric and the shocks have a one-unit variance. Therefore, $\frac{n(n+1)}{2}$ orthogonalization and normalization constraints have already been imposed. Thus, it is necessary to determine the 10 remaining constraints by relying on the economic literature. First, we assume that the world risk aversion shock (the shock on the variable VIX) is contemporaneously exogenous to domestic variables in the Eurozone countries. Indeed, VIX as a proxy for global non-European financial conditions is expected to affect the European financial markets in a first step and then to be impacted by the impaired conditions in the European countries through a feedback effect only in a second step (Gonzalez-Hermosillo and Johnson (2014)). Going further, Favero and Giavazzi (2008) consider that the US economy behaves as a closed economy and is therefore not impacted by economic conditions in Eurozone countries, which justifies that they order the US variables first. Second, we assume that the real variables (GDP and fiscal space) react with a lag to financial disturbances (national and international: spreads and VIX) and to the composition of debt due to reaction delays (Prieto et al. (2013), Favero and Giavazzi (2008), Kim (2005)). Therefore, given the ordering in the $Y$ matrix, the $P$ matrix of restrictions is defined as: 


$$
P=\left(\begin{array}{ccccc}
1 & 0 & 0 & 0 & 0 \\
P_{21} & 1 & P_{23} & P_{24} & P_{25} \\
P_{31} & P_{32} & 1 & P_{34} & P_{35} \\
0 & 0 & 0 & 1 & P_{45} \\
0 & 0 & 0 & P_{54} & 1
\end{array}\right)
$$

\subsection{Interpretation of results}

We present the panel whole sample's reactions to the different shocks in Appendix A and focus here on the reactions that address the dynamics of home bias. The distinct impulse response functions show the responses of the domestic variables and the global financial conditions indicator following each shock. They were generated using the Bayesian Monte-Carlo integration method proposed by Sims and Zha (1999). The standard errors associated with a one standard error deviation shock were calculated with the same method. ${ }^{11}$ The associated variance decompositions, which allow for a comparison of the relative importance of each shock in explaining the dynamics of the distinct variables, are displayed in Appendix B.

First, Figure 2 shows that an unexpected shock on fiscal space triggers a positive
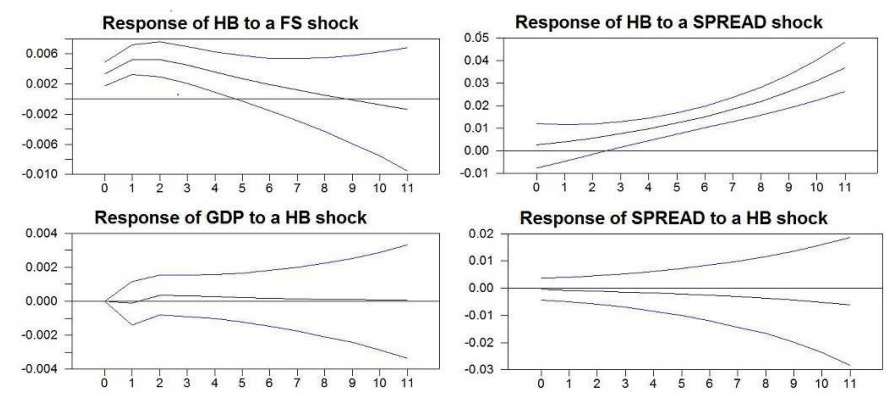

Figure 2: Main impulse response functions

significant response in home bias. This means that fundamental reasons can ex-

\footnotetext{
${ }^{11}$ The confidence interval calculated from the procedure proposed by Sims and Zha (1999) outperforms other procedures for short horizons (Kilian and Chang (2000)). Error bands correspond to the $16 \%$ and $84 \%$ quartiles. Results are significant if the confidence interval does not include the 0 axis.
} 
plain the increase in home bias. In addition, home bias responds to an unexpected shock on spreads with some lag. This result is in accordance with Broner et al. (2013)'s model (where the marginal buyer of sovereign bonds becomes a domestic one when the expected probability of default increases), and with the empirical investigation of Andritzky (2012).

Therefore, home bias seems to react to impaired credit risk fundamentals and expectations. Indeed, we interpret the shock on sovereign bonds spreads as a shock on expectations because it represents a one standard error deviation in the risk premium, with all of the other endogenous variables of the empirical model, particularly the fiscal space variable, remaining constant. This shock can affect home bias dynamics through various intermediary channels. They relate to distinct incentives for domestic and foreign creditors to invest in domestic sovereign debt, that arises when the probability of default increases (see the theoretical section for more details).

Home bias in sovereign debt responds positively to shocks on VIX and negatively to shocks on GDP after some lag. ${ }^{12}$ Both results are intuitive. First, when global risk aversion unexpectedly increases, foreign investors may become more cautious and invest less in foreign public debt, particularly the most risky debt. Second, an unexpected increase in GDP provides a comforting signal on the fundamental economic situation of a particular country, which causes foreign investors to increase their participation on the sovereign debt market of this country. The variance decomposition (see Appendix B) reveals that the shock on sovereign bonds spreads explains $23.92 \%$ of the variation of home bias 3 quarters after the shock and more than $40 \% 12$ quarters after the shock. The fundamental shock explains $7.3 \%$ of the variation in home bias 3 quarters after the shock, whereas the shock on GDP

\footnotetext{
${ }^{12}$ Home bias starts to increase before the period of deep stress on the Eurozone sovereign bonds markets in most countries of the sample. This suggests that global shocks related to the global financial crisis, such as shocks on VIX, might be more explanatory of home bias dynamics than country specific shocks in the beginning of the period.
} 
explains $2.12 \%$ of this variation and the shock on VIX less than $0.30 \%$ in the first periods when it is significant. Consequently, we will include in our theoretical model a change in fundamentals and a change in country-specific sovereign default expectations as the two main sources of increase in home bias.

Another important result for the assumptions of our theoretical model is the causality effect of a shock on home bias on the dynamics of the growth rate. We do not interpret the increase in home bias observed in our sample as a shock on home bias but rather as the response of home bias to shocks on other variables. Nonetheless, we use the results of our S-VAR to analyze the causality impact of an increase in home bias, when all of the other variables of the model remain constant. The theoretical literature emphasizes a possible destabilizing effect of home bias through crowding-out effects. Indeed, Broner et al. (2014) show that, due to financial frictions, increasing incentives for domestic investors to buy public debt when interest rates increase disrupt productive investment, which in turn reduces growth. Another possible effect of increasing home bias on the growth rate may be related to its impact on domestic banks' credit supply. Banks' credit supply may be reduced if banking risk increases due to banks' exposure to sovereign risk, eventually reducing investment and growth (Acharya et al. (2012)). Nevertheless, we cannot find empirical evidence of this effect: the growth rate does not significantly respond to a shock on home bias in sovereign debt in our sample.

One possible explanation for this result could be that the effect on growth is not due to home bias in sovereign debt but rather to home bias in banks' portfolios, which directly affects the private credit supply. Thus, the literature on the credit crunch following the sovereign debt crisis (see for instance Popov and Van Horen (2013)) has focused on this last variable. In addition, the impact, if any, of home bias on the growth rate is likely to be indirect and to not occur in the short run. In particular, Cantero-Saiz et al. (2014) show that in periods of easy monetary policy, no systematic linear relationship between sovereign risk and credit supply exists 
in Europe. Additionally, our empirical result may relativize the extent of the financial frictions and the prominence of residents in domestic productive investment assumed in the theoretical literature (see Broner et al. (2014)). Consequently, because we cannot find empirical grounds to plead for a negative effect of home bias on the growth rate in our sample, we choose not to include it in our theoretical model.

Similarly, a shock on home bias does not affect the dynamics of the spreads. This result seems rather intuitive: it is likely to reflect the fact that no precise public data on home bias is available every quarter, which explains that it is not precisely integrated in the market pricing of risk. This means that an increase in home bias does not reinforce or reduce self-fulfilling dynamics.

Our empirical results are robust to changes in the proxy variables. ${ }^{13}$

Now that we have identified the most important sources of exogenous variation in home bias in our empirical model, we examine their impact on the equilibrium of a second-generation model of sovereign debt crisis. This allows us to characterize the conditions under which an increase in home bias is associated with sovereign default.

\section{A simple model of self-fulfilling debt crisis with home bias}

We propose a second-generation model of crisis applied to sovereign debt crises in a monetary union. Our setting is a two-period strategic game involving three different players: domestic investors, foreign investors and the government.

\footnotetext{
${ }^{13}$ We substituted the quarter-on-quarter change in growth rate with the year-on-year change in growth rate and the spread on sovereign bonds with the premium on sovereign CDS. In addition, once we removed alternatively Germany and France from the sample (which possess distinct characteristics relative to peripheral countries), the results were not significantly different.
} 
In period 1, each individual investor - be it domestic or foreign -decides which share of its initial wealth to consume. The investor allocates the remaining part of its wealth between sovereign bonds and a world risk-free asset to maximize the inter-temporal utility of his consumption. Both domestic and foreign investors know how the government makes its decision. Nevertheless, ex-ante, they do not know if the outcome will be default or not. Indeed, an exogenous worldwide random macroeconomic shock $r$ occurs between period 1 and period 2 , and this shock affects the government's decision. Investors know the distribution of shock $r$ but they do not observe its realization before making their decision. Consequently, the probability of default that investors consider in their maximization program is integrated over the whole distribution of $r$. Therefore, the market interest rate reflects the uncertainty on the ex-post outcome. The timeline is displayed in Figure 3.

\subsection{The government's decision}

In period 2 (the final period of the game), the government observes the aggregate decision of domestic and foreign investors and the macroeconomic exogenous shock and decides between paying back the debt (which in period 2 includes interest rate payments) or defaulting on its full debt. ${ }^{14}$ Debt has a one-period maturity. In period 1, the government rolls over the totality of the debt inherited from the past $d_{1}$. Following Gennaioli et al. (2014) and Mengus (2013), the government is non-discriminatory in our model. This non-discrimination can be justified in their framework by trading on the secondary market and the portfolios' unobservability. In our model, non-discrimination is justified by the one-period maturity of debt: if the government was expected to default only on foreign creditors, foreign-

\footnotetext{
${ }^{14} \mathrm{We}$ focus on the binary alternative between full repayment and full default without taking into account the possibility of a partial haircut on debt. Nevertheless, the mechanism and results of the model would be similar when allowing for a haircut.
} 
ers could stop rolling over their holdings of sovereign debt anytime. ${ }^{15}$

A competitive equilibrium of our model is defined by a set of aggregate in-

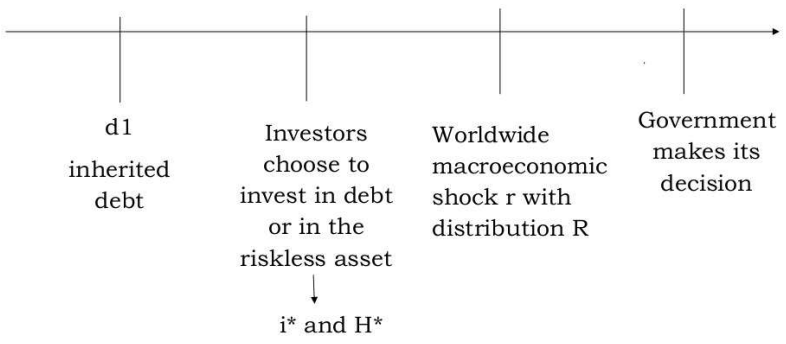

Figure 3: Timeline of the sequential game

vestors' decisions $\left(i^{*}, H^{*}\right)$, the realization of the macroeconomic worldwide exogenous shock $r$ and the government's decision (default or non-default). To make its decision regarding fiscal policy, the government strategically compares its loss function under full debt repayment with its loss function under full default, and chooses the least costly option. The optimizing government focuses on minimizing the economic and political costs of its fiscal policy.

We characterize the two distinct loss functions associated with the different fiscal policy strategies of the government. On the one hand, the loss associated with full repayment of the debt $L_{f}$ is related to the cost of taxation on debt $u\left(H, d_{1}, i\right)$, with $0<H<1$ the home bias (the proportion of debt held domestically) and $d_{1}$ the amount of debt inherited from the past. Indeed, when the government fully re-

\footnotetext{
${ }^{15}$ After the government makes its decision regarding default, the monetary policy authority - in the Eurozone, the ECB - can take action in order to avoid a sovereign default. Indeed, it can affect the government's political costs (notably, the cost of default), grant rescue loans with preferential conditions, buy government debt at lower interest rates on the secondary market, and refinance banks that are holding sovereign bonds. In addition, the ECB can affect ex-ante expectations, notably through liquidity injections and commitment or announcement that it will intervene to help countries facing difficulties. Endogenizing the ECB's strategic decision is beyond the scope of this paper because it is unlikely to be affected by home bias.
} 
pays its debt, it must finance it through taxation ${ }^{16}$ which is supported by domestic taxpayers. We have:

$$
\frac{\partial L_{f}}{\partial u}>0, \frac{\partial u}{\partial H}<0
$$

Indeed, domestic taxpayers are less reluctant to pay taxes for financing sovereign debt when they are the ones holding it (Gros (2012)) and the economic distortions related to taxation are lower if taxation allows at least the provision of liquidity to residents through repayment on the assets they are holding. Therefore, the cost of taxation is decreasing in home bias. This cost can alternatively be interpreted as a cost of austerity which is similarly faced by residents only.

The total amount of debt to be paid back by the government in period 2 is:

$$
d_{2}=d_{1}(1+i)
$$

the debt inherited from the past $d_{1}$ enhanced by the service of the debt. We have:

$$
\frac{\partial L_{f}}{\partial d_{1}}>0, \frac{\partial L_{f}}{\partial i}>0
$$

because the higher the total amount of debt, the higher the taxes to be collected. Eventually,

$$
\frac{\partial L_{f}}{\partial r}<0
$$

because the higher that $r$ is, the better the state of the economy. ${ }^{17}$

Therefore, the government's loss function associated with the decision to fully

\footnotetext{
${ }^{16}$ Because we are interested in the government's decision in the final period of the model, debt and interest payments cannot be funded through a new emission of debt in this last period.

${ }^{17}$ Empirically, this shock could be interpreted as a shock that lowers growth rates globally, such as a financial crisis or decline in world trade.
} 
repay the debt $L_{f}$ is defined as follows:

$$
L_{f}\left(\underset{+}{u}, d_{+}, \underset{-}{r}, \underset{-}{H}, \underset{+}{i}\right)
$$

The specificity of such a loss function in a monetary union is that national governments do not control monetary policy and thus cannot monetize debt (Corsetti and Dedola (2011)), which reinforces the impact of the cost of taxation on the government's decision. This specificity also renders the Eurozone countries more prone to self-fulfilling crises due to liquidity shortages converting into solvency crises (De Grauwe and Ji (2013)). We assume that $L_{f}$ is convex in all of its arguments and that $\lim _{d_{1} \rightarrow 0} L_{f}=0$ and $\lim _{d_{1} \rightarrow+\infty} L_{f}=+\infty$.

However, when the government defaults on its full debt, it faces a cost due to creditors' opposition to default.

A key new feature of our model is that we distinguish between two components of the political and economic costs of default: the cost of default on the debt held domestically $v_{D}\left(H, d_{1}, i\right)$ and the cost on the debt held abroad $v_{F}\left(H, d_{1}, i\right)$. This makes the share of domestic debt crucial to the government's decision, all the more so because the cost of taxation also depends on this variable.

The domestic cost of default increases with home bias (Mengus (2013), Kremer and Mehta (2000)) because the volume of domestic public debt increases for a given $d_{1}$ and because it makes residents more reluctant to default. Acharya et al. (2014) and Gennaioli et al. (2014) relate the internal domestic cost of default to domestic banks' holdings of domestic sovereign bonds. Gennaioli et al. (2014) provide evidence that the larger the exposure of domestic banks to sovereign risk, the more costly the default for the domestic economy through its ex post impact on private 
credit. $^{18}$

Conversely, the foreign cost of default decreases with home bias: ${ }^{19}$

$$
\frac{\partial v_{D}}{\partial H}>0, \frac{\partial v_{F}}{\partial H}<0
$$

The government's loss function in the case of default $L_{d}$ increases in both costs of default. We assume that: $v_{D}>v_{F}$ and $\frac{\partial L_{d}}{\partial v_{D}}>\frac{\partial L_{d}}{\partial v_{F}}$.

This means that the cost of default on the debt held domestically is higher than that on the debt held abroad and that a hike in the domestic cost of default leads to a stronger increase in the loss function than a change in the foreign cost of default. ${ }^{20}$ As a result,

$$
\frac{\partial L_{d}}{\partial H}>0
$$

Similarly to the loss function under full debt repayment, the loss function under default increases in $d_{1}$ and $i$ but, contrary to the loss function under full debt repayment, it increases in $r$.

Following Gros (2012), the loss function increases in $L>0$, which is an exogenous lump-sump cost of default. This can be empirically interpreted as the reputation cost that the government faces as soon as it defaults, whatever the amount of debt defaulted upon.

The loss function associated with the decision of default $L_{d}$ is the following:

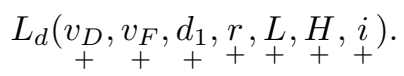

\footnotetext{
${ }^{18}$ The example of Japan also pleads for such an argument: Japanese public debt represents more than $200 \%$ of GDP but yields on sovereign bonds remain low (below $2 \%$ in the last years) due to the high confidence of investors in the credibility of the Japanese government to repay its debt.

${ }^{19}$ Notice that those different effects on political and economic costs would also be present if the government only defaulted (or repaid) part of its debt.

${ }^{20}$ Appealing reasons for those last points are that domestic debt holders hold political power thanks to their voting rights that foreign debt holders do not have and that default on debt held at home directly affects the domestic economy.
} 
We assume that $L_{d}$ is convex in all of its arguments and that $\lim _{d_{1} \rightarrow 0} L_{d}=L$ and $\lim _{d_{1} \rightarrow \infty} L_{d}=\infty$.

Because default is more likely when the debt to GDP ratio and interest rates are higher, we impose that:

$$
\frac{\partial L_{f}}{\partial i}>\frac{\partial L_{d}}{\partial i}, \frac{\partial L_{f}}{\partial d_{1}}>\frac{\partial L_{d}}{\partial d_{1}}
$$

We now solve the model by backward induction to characterize the government's decision and thus the equilibrium once investors have made their decision to determine the Nash equilibria of the game.

In period 2, the government observes $i^{*}$ and $H^{*}$ resulting from the investors' decision in period 1. The government makes its decision given the value of those variables and the value of the exogenous variables $d_{1}, r$ and $L$.

The government decides not to default when:

$$
L_{f}\left(u, d_{1}, r, H^{*}, i^{*}\right)-L_{d}\left(v_{D}, v_{F}, d_{1}, r, L, H^{*}, i^{*}\right) \leq 0,
$$

that is when its losses under full debt repayment are lower than its losses under default, and vice versa.

Therefore, a sufficient condition for having multiple equilibria conditional on expectations and home bias for a given fundamental is the following:

$\exists 2$ pairs $\left(i^{* 1}, H^{* 1}\right)$ and $\left(i^{* 2}, H^{* 2}\right)$ such that there exists at least one value of $d_{1}$ such that: $L_{d}\left(v_{D}, v_{F}, d_{1}, r, L, H^{* 1}, i^{* 1}\right)>L_{f}\left(u, d_{1}, r, H^{* 1}, i^{* 1}\right)$ and $L_{d}\left(v_{D}, v_{F}, d_{1}, r, L, H^{* 2}, i^{* 2}\right)<L_{f}\left(u, d_{1}, r, H^{* 2}, i^{* 2}\right)$. When this condition is satisfied, multiple equilibria arise for fundamental values included between $d_{1 \text { inf }}$ and $d_{1 \text { sup }} . d_{\text {inf }}$ is the unique fundamental value such 
that: $^{21}$

$$
L_{d}\left(v_{D}, v_{F}, d_{1}, r, L, H^{* 2}, i^{* 2}\right)=L_{f}\left(u, d_{1}, r, H^{* 2}, i^{* 2}\right) .
$$

$d_{1 \text { sup }}$ is the unique fundamental value such that:

$$
L_{d}\left(v_{D}, v_{F}, d_{1}, r, L, H^{* 1}, i^{* 1}\right)=L_{f}\left(u, d_{1}, r, H^{* 1}, i^{* 1}\right) .
$$

The range of the multiple equilibria zone is given by:

$$
d_{1 \text { sup }}-d_{1 \text { inf }}
$$

For fundamental values lower than $d_{1 i n f}$, whatever the market interest rate $i$ and the realization of the exogenous macroeconomic shock $r$, the debt-to-GDP ratio is so low that the government would never choose to default. For fundamental values higher than $d_{1 \text { sup }}$, whatever $i$ and $r$, the government would never choose to fully repay its debt. Figure 4 provides a graphical example of multiple equilibria conditional on the interest rate and home bias. For any fundamental value $d_{1}^{\prime}$ such that $d_{1 \text { inf }}<d_{1}^{\prime}<d_{1 \text { sup }}$, in case 1 , the government prefers to service its full debt because $L_{d}^{1}<L_{f}^{1}$ in the intermediary zone. In case 2, the government prefers to default because $L_{f}^{2}<L_{d}^{2}$ in the intermediary zone.

\subsection{Investors' decision under uncertainty}

Individual demand for domestic sovereign bonds is given by: $\omega(i)\left(W_{1}-C_{1}\right)$ where $W_{1}$ is the individual initial endowment in period 1 (similar for domestic and foreigners), $C_{1}$ is consumption in period 1 , and $\omega$ is the share of post-consumption wealth that is allocated to domestic sovereign bonds (with $1-\omega$ the share invested in the risk-free world asset).

\footnotetext{
${ }^{21}$ This value exists since $L_{d}=L$ and $L_{f}=0$ when $d_{1}=0$ and $\frac{\partial L_{d}}{d_{1}}<\frac{\partial L_{f}}{\partial d_{1}}$. It is unique since $L_{f}$ and $L_{d}$ are strictly monotonous in $d_{1}$.
} 


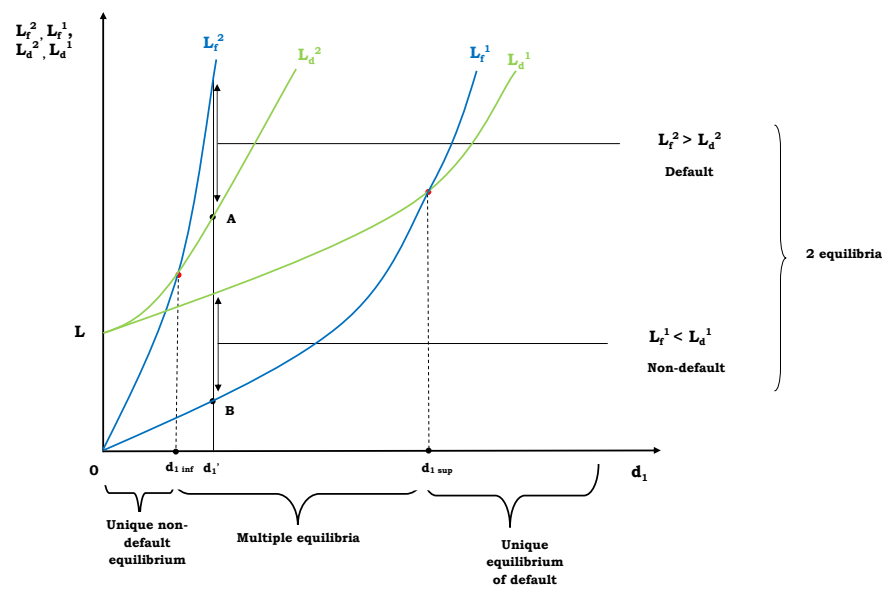

Figure 4: Pure non-default zone, multiple equilibria region and pure default zone

Because domestic investors represent a continuum on the $[0 ; 1]$ interval, aggregate domestic demand for domestic sovereign bonds is: $Q_{D}(i)=\omega_{D}(i)\left(W_{1}-C_{1}\right)$. Similarly, foreign demand for domestic sovereign bonds is:

$Q_{F}(i)=\omega_{F}(i)\left(W_{1}-C_{1}\right)$.

The risk-free asset provides an exogenous constant return: $E\left(R_{f}\right)=R_{f}$. In the midst of a stressful episode on the sovereign debt market, the market interest rate $i$ does not exactly represent what an investor will gain from investing in sovereign debt if no default occurs. Indeed, some particular benefits or costs that are increasing in the probability of default are added to the return on sovereign bonds for domestic and foreign investors.

As emphasized in the empirical literature, in the context of the Eurozone debt crisis, incentives to invest in the sovereign debt of the most fragile economies have decreased for foreign investors and increased for domestic ones. Battistini et al. (2013) (p.14) identified several types of increasing incentives for residents (partic- 
ularly banks) to invest in their own sovereign debt in fragile economies of the Eurozone. ${ }^{22}$ We thus include additional costs (for foreign investors) and benefits (for domestic investors) to invest in domestic sovereign debt in the model. These costs determine the difference between the domestic and foreign demands for sovereign bonds and thus the equilibrium home bias.

Due to the random macroeconomic shock $r$ that occurs after the investors make their decision, the investors cannot know for sure what the government's decision will be, even if they can observe or anticipate the value of all other variables. Consequently, in their maximization program, agents include the cumulative probability of default over the entire distribution of $r$ (the probability of having $L_{f}>L_{d}$ conditional on $r$ ).

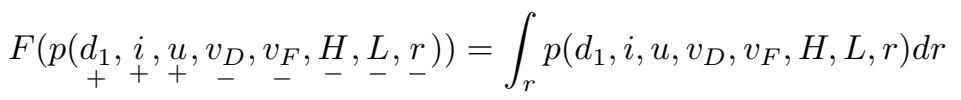

is the cumulative probability of default, included between 0 and 1. For simplicity, in what follows, we will (improperly) write it $p(i, H, r)$ for a given fundamental $d_{1}$, given functional forms $\left(u, v_{D}, v_{F}\right)$ and parameter $L$. Domestic sovereign bonds yield the following expected returns for domestic investors (given that the price of bonds is equal to their face value on the primary market):

$$
E\left[R_{i_{D}}\right]=i_{D}\left(i, b_{D}(p(i, H, r))\right) \cdot(1-p(i, H, r)),
$$

\footnotetext{
${ }^{22}$ The first one is the pressure government can exert on domestic banks to have them buy public debt, financial repression in the words of Reinhart and Sbrancia (2011). Financial repression in the recent Eurozone debt crisis was thoroughly documented by Van Riet (2014). The second one is that undercapitalized banks, that are mostly located in peripheral countries, can choose to engage in 'carry-trades' by going long on more risky public debt and short on less risky one (see also Gennaioli et al. (2014)). The third one is related to a possible exit from the Eurozone, in which domestic investors would have a comparative advantage, as sovereign debt would be redenominated in national currency. In addition, expectations of a possible bailout of residents following a default (Mengus (2013)) can provide incentives for domestic purchases of debt.
} 
where $i_{D}\left(i, b_{D}(p(i, H, r))\right.$ represents the domestic interest rate - what a domestic investor really gains from the market interest rate $i$ once the additional benefits for the domestic investors $b_{D}(p(i, H, r))$ are included, which are increasing and convex in the probability of default.

Similarly, domestic sovereign bonds yield the following expected returns for foreigners:

$$
E\left[R_{i_{F}}\right]=i_{F}\left(i, c_{F}(p(i, H, r))\right) \cdot(1-p((i, H, r))),
$$

where $i_{F}$ represents the foreign implicit interest rate and $c_{F}(p(i, H, r))$ the additional costs for foreigners, which are increasing and convex in the probability of default. Given that domestic investors face additional benefits and foreign investors additional costs, this yields: $0<i_{F}()<i<.i_{D}($.$) . We now write i_{j}($.$) with$ $j=(D, F)$ the gain from the return received on domestic sovereign bonds for the two groups of investors. We first characterize the domestic and foreign demand of bonds for each value of the interest rate $i$.

The general program for a representative individual investor writes as follows:

$$
\max _{c_{1}, \omega_{j}} E_{1}\left[U\left(c_{1}, c_{2}\right)\right]=\max _{c_{1}, \omega_{j}} \ln \left(c_{1}\right)+\beta E_{1}\left[\ln \left(c_{2}\right)\right]
$$

s.t.

$$
\begin{gathered}
c_{1}+\frac{c_{2}}{1+E_{1}\left(R_{T}\right)}=W_{1}, \\
R_{T}=R_{f}+\omega_{j}\left(R_{i j}-R_{f}\right), \\
0 \leq \omega_{j} \leq 1 .
\end{gathered}
$$

The Lagrangian writes:

$$
L=\ln \left(c_{1}\right)+\beta E_{1}\left[\ln \left(\left(W_{1}-c_{1}\right)\left(1+R_{f}+\omega_{j}\left(R_{i j}-R_{f}\right)\right)\right]+\lambda_{j}\left(1-\omega_{j}\right) .\right.
$$


The Kuhn-Tucker conditions yield:

$$
\begin{gathered}
c_{1}^{*}=\frac{1}{1+\beta} W_{1}, \\
\omega_{j}^{*}=\max \left[\min \left(\frac{\left(1+R_{f}\right)\left(i_{j}(.) \cdot(1-p(i, H, r))-R_{f}\right)}{R_{f}\left(i_{j}(.)-R_{f}\right)}, 1\right), 0\right] . \\
\lambda_{j}^{*}=\max \left(\beta\left[p(i, H, r) \frac{-R_{f}}{1+R_{f}\left(1-\omega_{j}^{*}\right)}+(1-p(i, H, r)) \frac{i_{j}(.)-R_{f}}{1+R_{f}+\omega_{j}^{*}\left(i_{j}(.)-R_{f}\right)}\right], 0\right) .
\end{gathered}
$$

For a given interest rate on sovereign bonds, the domestic demand for sovereign bonds is equal to:

$$
Q_{D}(i)=\omega_{D}^{*}(i)\left(W_{1}-c_{1}^{*}\right)
$$

and the foreign demand for domestic bonds is equal to:

$$
Q_{F}(i)=\omega_{F}^{*}(i)\left(W_{1}-c_{1}^{*}\right)
$$

The interest rate has two effects on the demand function, playing in opposite directions. First, when the interest rate increases, the return on domestic public debt increases, which increases demand through a portfolio effect. Second, when the interest rate increases, the probability of default increases. Indeed, everything else being equal, a higher interest rate makes the loss function under default increase less than the loss function under debt repayment. For foreign investors, the increase in probability also increases the additional costs of investing in sovereign debt whereas it increases additional benefits for domestic investors.

We assume that: $\frac{\partial Q_{j}}{\partial i}>0$ on some interval of interest rates $\left[i_{1}, i_{2}\right]$, where $i_{1}$ is the lowest value of $i$ such that demand for sovereign bonds is non-null. This implies that on this interval, the positive effect of a marginal increase in the interest 
rate more than compensates its negative effect. ${ }^{23}$ In addition, we assume that $p$ is convex in $i$ (intuitively, the higher the interest rate, the higher the impact of its increase on the probability of default) and that both demand functions are concave in $i$ on the interval $\left[i_{1}, i_{2}\right]$ (this implies that the higher $i$ is on this interval, the lower its positive impact on demand relative to its negative impact, which is consistent with the fact that for high levels of $i$, the probability of default is likely to be close to 1 , for which the portfolio effect cannot compensate).

Given that the higher probability of default associated with a higher interest rate does not only have a negative impact on domestic demand but also a positive impact (because it raises the additional benefits of investing in sovereign bonds), we have: $\frac{\partial Q_{D}}{\partial i}>\frac{\partial Q_{F}}{\partial i},\left|\frac{\partial^{2} Q_{D}}{\partial i^{2}}\right|<\left|\frac{\partial^{2} Q_{F}}{\partial i^{2}}\right|$.

Market clearing To derive the equilibrium condition, we calculate the aggregate demand for a given $i\left(Q_{T}(i)=Q_{D}(i)+Q_{F}(i)\right)$ and set it equal to the supply:

$$
Q_{D}(i)+Q_{F}(i)=d_{1}
$$

A sufficient condition for obtaining a stable market equilibrium is that one value of $i_{1} \leq i \leq i_{2}$ such that $Q_{T}(i)=d_{1}$ (A) exists.

If total demand for sovereign bonds is too low relative to $d_{1}$ whatever the interest rate, there is no market equilibrium, leading to a roll-over crisis. This yields $i^{*}$ (and then $i_{H}^{*}$ and $i_{F}^{*}$ ) and $H^{*}$. Indeed,

$$
i^{*}=Q_{T}^{-1}\left(d_{1}\right),
$$

\footnotetext{
${ }^{23}$ This assumption allows us to obtain a monotonous increasing demand function in $i$ on the interval $\left[i_{1}, i_{2}\right]$ and thus, if any, the market equilibrium on this interval is a stable equilibrium. If $i_{2}$ is a finite number, the negative effect of a higher $i$ (through its positive impact on the probability of default) dominates for $i>i_{2}$ and we may obtain two market equilibria. The one on the decreasing part of the demand curve would be unstable, what justifies that, even in that case, we focus on the equilibrium in the increasing part. In addition, this assumption enables us to generate an increase in the market interest rate following an expectations shock, which is intuitive and consistent with empirical features.
} 
and

$$
H^{*}=\frac{\omega_{D}^{*}}{\omega_{D}^{*}+\omega_{F}^{*}}=\frac{\omega_{D}^{*}}{\omega_{T}^{*}} .
$$

Figure 5 illustrates the endogenous home bias.

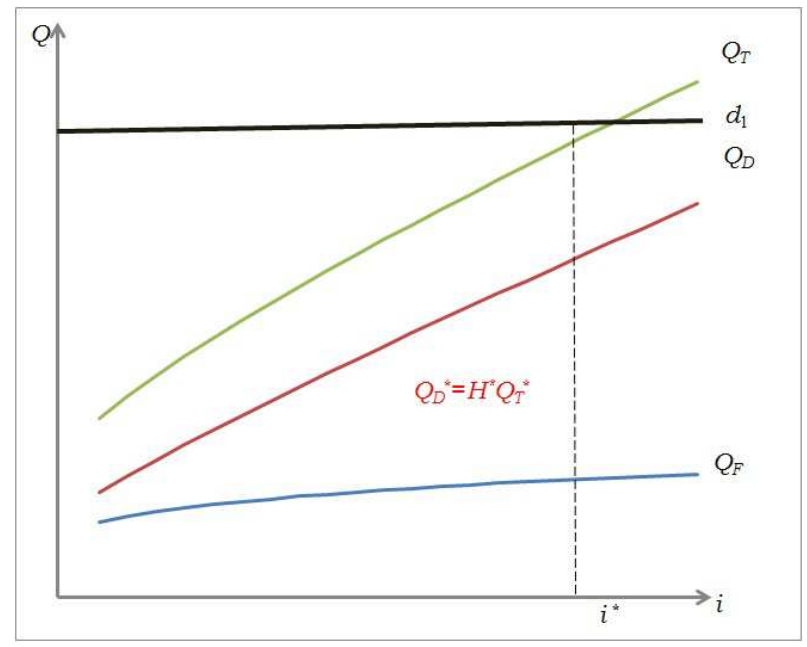

Figure 5: Endogenous home bias

\subsection{Change in equilibrium following an exogenous change in ex- pectations and in fundamentals}

We now assess the impact of an exogenous change in expectations and in the fiscal fundamentals on the model's equilibrium to replicate the increase in home bias and assess its impact on the government's decision.

Change in expectations We compare two different situations in which expectations differ for the same fundamental, as in any standard second-generation 
model of crisis. $^{24}$ More pessimistic expectations lower the demand for a given interest rate through the beliefs on beliefs of others. Indeed, if some exogenous shock on higher order beliefs occurs and agents (both domestic and foreign because they all have the same beliefs) think that others think that others (and so on) think that for a given $i, p(i)$ is actually higher, they are going to lower their individual demand for a given $i$. They know that others' beliefs on others are validated. If they lower their individual demand, aggregate demand decreases and supply does not shift, which gives rise to a new market equilibrium with a higher interest rate and therefore a higher equilibrium probability of default. Consequently, all agents lower their demand and expectations are validated. Market clearing is realized if and only if condition (A) is still satisfied. If not, the government faces a roll-over crisis and is pushed into default already in period 1.

Proposition 1: When expectations become more pessimistic, home bias always increases.

Proof. We write $Q_{F}\left(i^{*}\right)$ (respectively $\left.Q_{D}\left(i^{*}\right)\right)$ the foreign (respectively domestic) demand in equilibrium in the initial case and $Q_{F}^{\prime}\left(i^{\prime *}\right)$ (respectively $\left.Q_{D}^{\prime}\left(i^{\prime *}\right)\right)$ the foreign (respectively domestic) demand in equilibrium in the second case. Given that the gap between domestic demand in the situation with more pessimistic expectations and domestic demand in the situation with less pessimistic expectations is lower than that between foreign demand in the two respective situations, and given that domestic demand increases more strongly in $i$ than foreign demand, we

\footnotetext{
${ }^{24}$ The difference in our model is that expectations impact not only the government's decision through the market interest rate (that we endogenize with respect to expectations), but also through the associated home bias.
} 
have:

$$
\begin{aligned}
Q_{F}\left(i^{*}\right)-Q_{F}^{\prime}\left(i^{\prime *}\right) & =Q_{F}\left(i^{*}\right)-Q_{F}^{\prime}\left(i^{*}\right)+Q_{F}^{\prime}\left(i^{*}\right)-Q_{F}^{\prime}\left(i^{* *}\right) \\
& >Q_{D}\left(i^{*}\right)-Q_{D}^{\prime}\left(i^{*}\right)+Q_{D}^{\prime}\left(i^{*}\right)-Q_{D}^{\prime}\left(i^{\prime *}\right) \\
& =Q_{D}\left(i^{*}\right)-Q_{D}^{\prime}\left(i^{* *}\right) .
\end{aligned}
$$

The market clearing conditions in both situations yield:

$$
Q_{F}\left(i^{*}\right)-Q_{F}^{\prime}\left(i^{\prime *}\right)=-\left(Q_{D}\left(i^{*}\right)-Q_{D}^{\prime}\left(i^{\prime *}\right)\right),
$$

which implies that: $Q_{D}\left(i^{*}\right)-Q_{D}^{\prime}\left(i^{\prime *}\right)<0$, meaning that home bias is higher in the second situation relative to the first one.

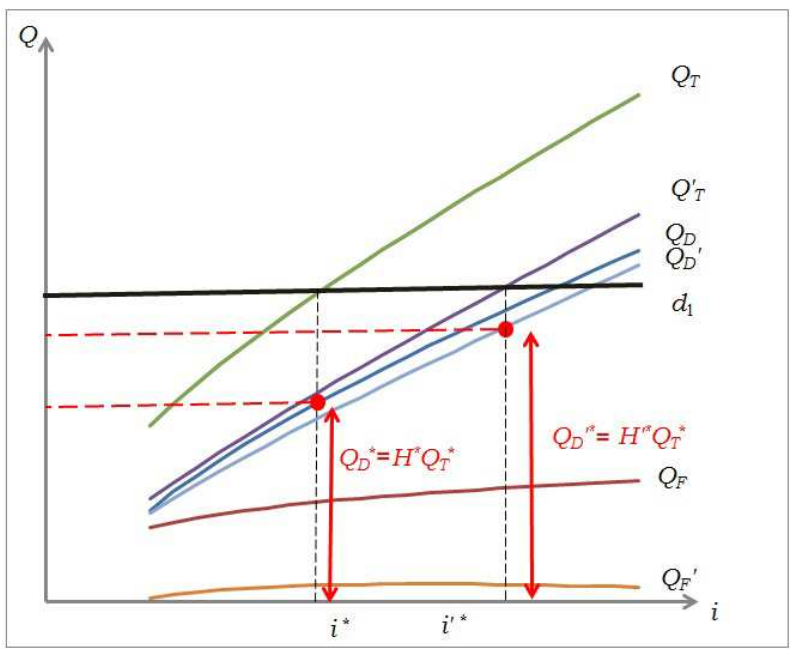

Figure 6: More pessimistic expectations and home bias

Therefore, the model replicates the stylized fact: more pessimistic expectations lead to higher market interest rate and home bias. We now assess the impact of such a change in investors' decision on government's decision when the market 
clears in the first period. Figure 6 provides a graphical example.

For both the change in expectations and the change in fundamentals that we study below, we consider the realization of the exogenous worldwide macroeconomic shock $r$ to be the same in the two cases that we compare. ${ }^{25}$

If we write $\left(i^{*}, H^{*}\right)$ the investors' decision in the initial situation and $\left(i^{*^{\prime}}, H^{*^{\prime}}\right)$ the investors' decision in the situation with more pessimistic expectations, we can derive the straightforward sufficient condition for a change in equilibrium:

A switch from the non-default equilibrium to the default equilibrium occurs if and only if: $L_{d}\left(i^{*}, H^{*}\right)>L_{f}\left(i^{*}, H^{*}\right)$ and $L_{d}\left(i^{*^{\prime}}, H^{*^{\prime}}\right)<L_{f}\left(i^{*^{\prime}}, H^{*^{\prime}}\right)$. (B)

The fundamental $d_{1}$, the functional forms of the model $\left(u, v_{D}, v_{F}\right)$, the parameter $L$ and the realization of $r$ are the same in both situations, because we are only interested in determining the effect of the expectations shock.

The distinct effects at work are the following. On the one hand,

$$
\frac{\partial L_{f}}{\partial i}>\frac{\partial L_{d}}{\partial i}
$$

In the situation with the expectations shock, the market interest rate $i$ is higher, which makes both the government's loss under default and the government's loss under full debt repayment increase. Nevertheless, it has a stronger impact on the loss function under default than on the loss function under full debt repayment. This leads to a destabilizing effect of the change in expectations (increase in the incentives to default).

On the other hand,

$$
\frac{\partial L_{f}}{\partial H}<0, \frac{\partial L_{d}}{\partial H}>0
$$

The increase in home bias following the change in expectations causes the increase in the loss function under default (through the increase in the cost of default),

\footnotetext{
${ }^{25}$ Thus, the change in equilibrium cannot be due to a change in the realization of the shock, which is not what we investigate here.
} 
whereas the loss function under full debt repayment decreases (through the decrease in the cost of taxation). This leads to a stabilizing effect (decrease in the incentives to default).

Consequently, a higher home bias does not lead per se to a switch in equilibrium. Nevertheless, if the change in expectations that triggered the increase in home bias is strong enough and the exogenous worldwide shock is bad enough given the new expectations, the sufficient condition (B) can be satisfied. In addition, because investors have rational expectations, the expectations shock must be justified by a hike in the probability of default, such that expectations are validated. This implies that to generate an increase in home bias in the model, the change in expectations must be strong enough to compensate the stabilizing effect of the hike in home bias, but this is not a sufficient condition for a change in the government's decision. This means that we have:

$$
L_{d}^{\prime}-L_{f}^{\prime}<L_{d}-L_{f}
$$

be it because $L_{d}^{\prime}-L_{f}^{\prime}$ becomes negative or simply because $L_{d}^{\prime}$ increases less than $L_{f}^{\prime}$ (in comparison respectively with $L_{d}$ and $L_{f}$ ).

Change in fundamentals We now perform a similar comparative statics exercise to derive the effect of an exogenous increase in the fiscal fundamental on the equilibrium of the game. An increase in $d_{1}$ has both an effect on demand and on supply of domestic sovereign bonds. On the one hand, an increase in $d_{1}$ means that the exogenous supply increases. On the other hand, an increase in $d_{1}$ raises the ex ante probability of default, which is conditional on the fundamental. Consequently, in comparison with the situation with a lower fundamental, it decreases demand for a given $i$. Supply is higher and demand is lower, which causes the market interest rate to increase. 
Proposition 2: When the fundamental increases, home bias increases.

Proof. Proof of Proposition 2 is similar to Proof of Proposition 1 except that the change in the fundamental must be taken into account.

A graphical illustration is provided in Figure 7.

If we now insert these new endogenous variables in the government's decision,

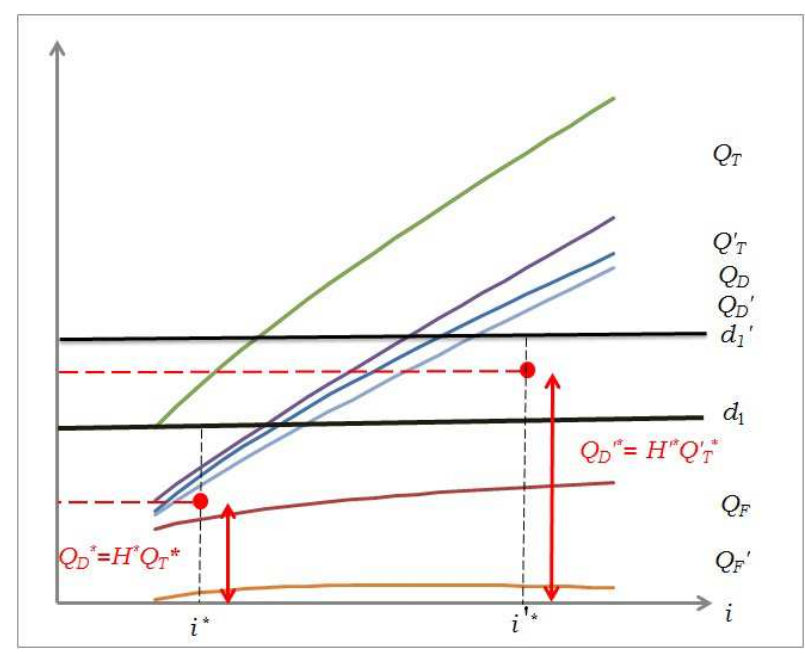

Figure 7: Increase in fundamental and home bias

a switch from the non-default equilibrium to the default equilibrium occurs if and only if: $L_{d}\left(d_{1}, i^{*}, H^{*}\right)>L_{f}\left(d_{1}, i^{*}, H^{*}\right)$ and $L_{d}\left(d_{1}^{\prime}, i^{*^{\prime}}, H^{*^{\prime}}\right)<L_{f}\left(d_{1}^{\prime}, i^{*^{\prime}}, H^{*^{\prime}}\right)$. (C) The distinct effects at work are the following. On the one hand, the increase in the debt-to-GDP ratio and in the interest rate increases the probability of default. On the other hand, the increase in home bias has a stabilizing effect. Condition (C) provides a sufficient condition for a change in equilibrium.

Therefore, an increase in home bias reflects an exogenous source of fragility that can lead to a switch in equilibrium, but this is not an ex-post additional source of fragility itself. On the reverse, it plays as a stabilizing mechanism - through political costs - that mitigates the effect of the ex-ante source of fragility that triggered 
it, and makes the sufficient condition for a switch in equilibrium less likely.

Therefore, we have identified a sufficient condition, both in the case of a change in expectations and a change in the fiscal fundamental, such that the situation that triggers an increase in home bias ends up in sovereign default. Nevertheless, if this condition is not satisfied, defaulting remains suboptimal for the government, either because home bias increases enough to partly compensate for the deteriorating macroeconomic conditions or because those conditions have not deteriorated enough. The next section provides a discussion on which case of the model best represents what recently occurred in the distinct Eurozone countries.

\section{Which case of the model best applies to the Euro- zone debt crisis? A factual discussion}

The model replicates recent stylized facts in the Eurozone - the increase in home bias associated with an increase in bond yields and episodes of partial default. The model explains two distinct cases for countries where home bias in public debt has increased. First, it replicates the case of countries where sovereign default or debt repayment conditional on rescue plans has occurred following a destabi-

lizing fiscal shock. Second, it explains the case of countries where governments repaid their debt despite impaired conditions. Regarding our sample period, it is possible to identify which countries have satisfied the sufficient condition for the government's equilibrium to change following the increase in home bias. The only country that has defaulted on part of its debt in our sample is Greece. A first rescue package consisting of loans from the IMF and bilateral loans from the other Eurozone countries was allowed to Greece in May 2010, amounting to approximately 80 billion euros between May 2010 and June 2013. Default on part of the debt occurred later, in the context of the second rescue plan (October 2011) for 
Greece. The IMF and the EFSF allocated new loans amounting to 130 billion euros in addition to the final payments of the first Economic Adjustment Programme to Greece for the years 2012 to 2014, conditional on new austerity measures and the realization of so-called private sector involvement. The new loans required voluntary debt swaps from private creditors who were subject to Greek law. This implied a haircut of $53.5 \%$ in nominal terms and a conversion of the remaining debt into new long-term Greek government bonds, short-term EFSF notes and detachable GDP-linked securities. Later, the collective action clause was activated to constrain creditors who refuse to agree to the debt swap, which led to the activation of Greek sovereign CDS. Greek partial default on government debt finally took place in March 2012.

More generally, the change in the government's equilibrium condition can be seen as satisfied for countries that have requested rescue packages from the EFSF, such as Ireland, Portugal and more recently Spain. In our theoretical framework, this can be interpreted as those countries reaching the point where default would have become more beneficial than debt repayment if no help was provided, leading them to request a rescue package. In those countries, the increase in home bias did not prevent from a change in the government's equilibrium.

In Ireland, an Economic Adjustment Programme was agreed in December 2010 and covered the period 2010 to 2013, for an amount of 85 billion euros. Portugal benefited from a similar programme, agreed in May 2011, covering the period 2011 to 2014, amounting to 78 billion euros. The case of Spain is slightly different because the support package agreed in July 2012 (representing 100 billion euros) was directed to the recapitalization of financial institutions.

In our theoretical framework, this can be interpreted as those countries reaching the point where default has become more beneficial than debt repayment if no help is provided, leading them to request to be granted a rescue package. Therefore, in the case of the countries of our sample mentioned here above, the increase 
in home bias has clearly not been stabilizing enough relative to the negative impact of the shocks that have triggered it. It has not prevented from a change in the government's equilibrium.

Regarding the remaining countries where home bias has increased in our sample, the case of the model that would best apply to those countries is the one in which the destabilizing shocks occurring throughout the period of stress were not strong enough to cause default to become more beneficial for governments. This may be partly due to the possibly stabilizing effect of the increase in home bias that may have played a larger role in some countries than in others due to distinct taxation and domestic default costs among countries. Nevertheless, this can also be explained by the fact that country-specific expectations were less pessimistic or fiscal situations less critical for those countries relative to the countries for which the sufficient condition for a change in the government's decision has held true at some point during the period. In the French case in particular, the increase in home bias has been more recent and less significant, with the volume of debt held abroad stagnating but not decreasing, and has been associated with decreasing yields, which suggests that the shock that triggered the increase in home bias was a much less negative expectations shock (or even a positive expectations shock) relative to what occurred in other countries. Therefore, if the sufficient condition for a change in the government's decision following an increase in home bias has not held true in France, this is most likely due to the more positive perceptions of foreign investors rather than to any stabilizing effect of home bias.

Consequently, it is possible to empirically identify in our sample the countries that have faced a change in the government's decision regarding the decision of default and the countries that have not faced such a change in the period when home bias increased, revealing distinct sensitivities to home bias and/or sufficiently distinct fiscal situations and perceptions from investors on the sovereign bond market. 


\section{Conclusion}

Empirical investigation enables us to identify two main shocks that affect the

dynamics of home bias: fundamental shocks and country-specific expectations shocks. We find no evidence that a higher home bias is destabilizing per se, which relativizes the view held in the theoretical literature. Thanks to a secondgeneration model of sovereign debt crisis shedding light on the costs of default and taxation, we emphasize the possibility of multiple equilibria conditional on expectations and home bias. Introducing a change in expectations and a change in fundamentals as sources of variation in the variables and parameters, we show that a switch in the government's fiscal decision is conditional on the relative effect of the increase in home bias and of the source of fragility that triggered the increase.

Therefore, the relaxation of capital controls to decrease home bias does not seem to be a relevant measure for limiting sovereign default risk in the Eurozone because, if any, the increase in home bias has a stabilizing effect. Our results support the idea that the Eurozone economies could withstand turmoil periods on sovereign debt markets as long as the share of debt held domestically is high enough relative to the initial destabilizing shock. This makes national governments' will to repay their debt more credible by allowing less politically costly transfers from debt holders to taxpayers. More worrying is the impact of an increasing home bias in banks' portfolios, which can justify policies favoring diversity amongst domestic debt holders. However, identifying the drivers of the increase justifies ECB interventions on sovereign bonds markets to avoid expectations or fundamental shocks. If efficient in restoring confidence, those measures would limit the transmission of sovereign risk to banking risk and induce foreign investors to return to the domestic sovereign debt market in the longer term. 


\section{References}

Acharya, V., Drechsler, I., and Schnabl, P. (2012). A Tale of Two Overhangs: the Nexus of Financial Sector and Sovereign Credit Risks. Financial Stability Review, 16: 51-56.

Acharya, V. V., Drechsler, I., and Schnabl, P. (2014). A Pyrrhic Victory? Bank Bailouts and Sovereign Credit Risk. Journal of Finance, Forthcoming.

Aguiar, M., Amador, M., Farhi, E., and Gopinath, G. (2014). Coordination and Crisis in a Monetary Union. Mimeo.

Aizenman, J., H. M. and Jinjarak, Y. (2013). What is the Risk of European Sovereign Debt Defaults? Fiscal Space, CDS Spreads and Market Pricing of Risk. Journal of International Money and Finance, 34: 37-59.

Andritzky, J. (2012). Government Bonds and Their Investors: What Are the Facts and Do They Matter? IMF Working Paper, (158).

Arslanalp, S. and Tsuda, T. (2012). Tracking Global Demand for Advanced Economy Sovereign Debt. IMF Working Paper, (284).

Battistini, N., Pagano, M., and Simonelli, S. (2013). Systemic Risk and Home Bias in the Euro Area. European Commission Economic Papers, (494).

Beetsma, R., Giulodori, M., and Klaasen, F. (2006). Trade Spill-overs of Fiscal Policy in the European Union: a Panel Analysis. Economic Policy, 21(48): 639-687.

Blot, C., Ducoudre, B., and Timbeau, X. (2014). Sovereign Debt Spread and Default in a Simple Model with Self-fulfilling Prophecies and Asymmetric Information. OFCE Working Paper.

Borenzstein, E. and Panizza, U. (2009). The Costs of Sovereign Default. IMF Staff Papers, 56: 683-741.

Broner, F., Didier, T., Erce, A., and S., S. (2013). Gross Capital Flows: Dynamics and Crises. Journal of Monetary Economics, 60: 113-33.

Broner, F., Erce, A., Martin, A., and Ventura, J. (2014). Sovereign Debt Markets in Turbulent Times: Creditor Discrimination and Crowding-out Effects. Journal of Monetary Economics, 61: 114-142(forthcoming).

Bruneau, C., Delatte, A., and Fouquau, J. (2012). Is the European Sovereign Crisis Self-fulfilling? Empirical Evidence about the Drivers of Market Sentiments. OFCE Working Paper, (22).

Brutti, F. and Saure, P. (2013). Sovereign Debt Crises and Bond Ownership: Testing the Secondary Market Theory. Mimeo. 
Calvo, G. (1988). Servicing the Public Debt: the Role of Expectations. American Economic Review, 78(4): 647-661.

Canova, F. and Ciccarelli, M. (2013). Panel Vector Autoregressive Models: a Survey. ECB Working Papers Series, (1507).

Cantero-Saiz, M., Sanfilippo-Azofra, S., Torre-Olmo, B., and Lopez-Gutierrez, C. (2014). Sovereign Risk and the Banking Channel in Europe. Journal of International Money and Finance, (Accepted Manuscript).

Cole, H. and Kehoe, T. (2000). Self-fulfilling Debt Crises. Review of Economic Studies, 67: 91-116.

Conesa, J. and Kehoe, T. (2013). Gambling for Redemption and Self-fulfilling Debt Crises. Federal Reserve Bank of Minneapolis Staff Report, (465).

Corsetti, G. and Dedola, L. (2011). Fiscal Crises, Confidence and Default. A Barebones Model with Lessons for the Euro Area. Mimeo.

Cruces, J. and Trebesch, C. (2013). Sovereign Defaults: the Price of Haircuts. American Economic Journal: Macroeconomics, 5(3): 85-117.

De Grauwe, P. (2011). The Governance of a Fragile Eurozone. CEPS working document, (346).

De Grauwe, P. and Ji, Y. (2013). Self-fulfilling Crises in the Eurozone: an Empirical Test. Journal of International Money and Finance, 34:15-36.

Dooley, M. and Hutchinson, M. (2009). Transmission of the U.S. Subprime Crisis to Emerging Markets: Evidence on the Decoupling-Recoupling Hypothesis. Journal of International Money and Finance, 28(8): 1331-1349.

Eaton, J. and Gersovitz, M. (1981). Debt with Potential Repudiation: Theoretical and Empirical Analysis. Review of Economic Studies, 48(2): 289-309.

Favero, C. and Giavazzi, F. (2008). Should the Euro Area be Run as a Closed Economy? American Economic Review, 98(2): 138-145.

Gennaioli, N., Martin, A., and Rossi, S. (2014). Sovereign Default, Domestic Banks and Financial Institutions. Journal of Finance, 69(2): 819-866.

Gonzalez-Hermosillo, B. and Johnson, C. (2014). Transmission of Financial Stress in Europe: The Pivotal Role of Italy and Spain, but not Greece. IMF Working Paper Series, (76).

Gros, D. (2012). A Simple Model of Multiple Equilibria and Default. CEPS Working document, (366). 
Kilian, L. and Chang, P. (2000). How accurate are Confidence Intervals for Impulse Responses in Large VAR Models? Economics Letters, 69: 299-307.

Kim, S. (2005). Monetary policy, Foreign Exchange Policy, and Delayed Overshooting. Journal of Money, Credit and Banking, 37(4):775-782.

Kremer, M. and Mehta, P. (2000). Globalization and International Public Finance. NBER Working Paper, (7575).

Lorenzoni, G. and Werning, I. (2013). Slow Moving Debt Crises. NBER Working Paper, (19228).

Mengus, E. (2013). Honoring Sovereign Debt or Bailing Out Domestic Residents? A Theory of Internal Cost of Default. Mimeo.

Merler, S. and Pisani-Ferry, J. (2012). Who's Afraid of Sovereign Bonds? Bruegel Policy Contribution, (02).

Obstfeld, M. (1994). The Logic of Currency Crises. NBER Working Papers, (4640).

Obstfeld, M. (1996). Models of Currency Crises with Self-fulfilling Features. European Economic Review, 40(3-5): 1037-1047.

Panizza, U., Sturzenegger, F., and Zettelmeyer, J. (2009). The Economics and Law of Sovereign Default. Journal of Economic Literature, 47(3): 651-698.

Popov, A. and Van Horen, N. (2013). The Impact of Sovereign Debt Exposure on Bank Lending: Evidence from the European Debt Crisis. DNB Working Paper, (382).

Prieto, E., Eickmeier, S., and Marcellino, M. (2013). Time Variation in MacroFinancial Linkages. CEPR Discussion Papers, (9436).

Reinhart, C. and Sbrancia, S. (2011). The Liquidation of Government Debt. NBER Working Paper, (16893).

Sims, C. (1988). Bayesian Skepticism on Unit root Econometrics. Journal of Economic Dynamics and Control, 12(2-3): 463-474.

Sims, C. and Uhlig, H. (1991). Understanding Unit Rooters: a Helicopter Tour. Econometrica, 59(6): 1591-99.

Sims, C. and Zha, T. (1998). Bayesian Methods for Dynamic Multivariate Models. International Economic Review, 39(4): 949-968.

Sims, C. and Zha, T. (1999). Error Bands for Impulse Responses. Econometrica, 67(5): 1113-1156.

Van Riet, A. (2014). Managing High Public Debt in Euro Area Countries: Financial Repression as a Fiscal Insurance? ECB Draft Document. 


\section{A Impulse response functions}

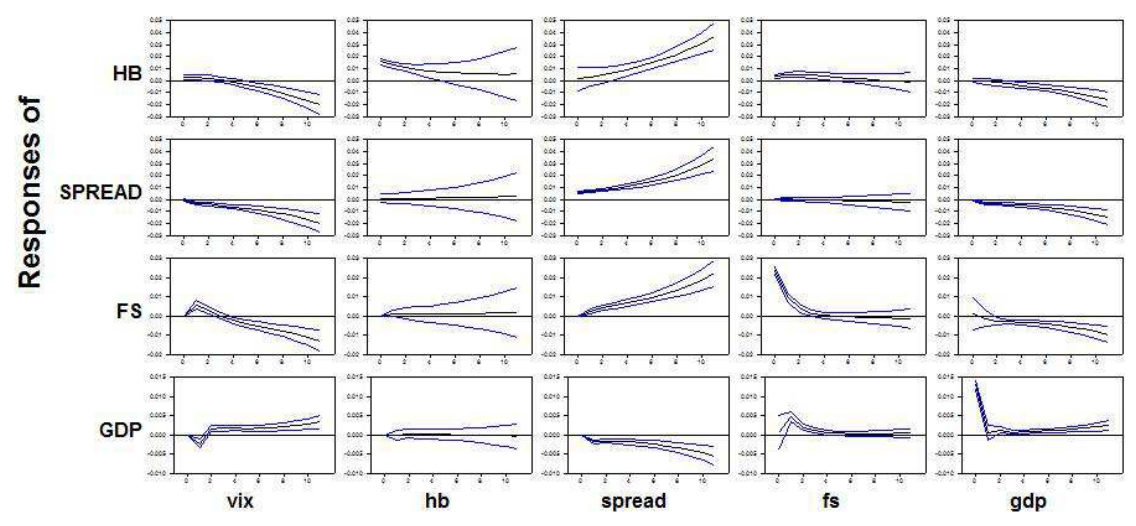

Figure 8: Impulse response functions

\section{B Variance Decompositions}

\begin{tabular}{|c|c|c|c|c|c|c|c|c|c|c|c|}
\hline Vix shock (\%) & Vix & hb & spread & fs & gdp & ppread shock (\%) & Vix & hb & spread & fs & gdp \\
1 & 99.88 & 0.11 & 0 & 0 & 0 & 1 & 0 & 36.12 & 63.88 & 0 & 0 \\
2 & 99.12 & 0.21 & 0.13 & 0.4 & 0.06 & 2 & 3.85 & 27.11 & 53.9 & 3.98 & 2.13 \\
3 & 98.7 & 0.27 & 0.31 & 0.5 & 0.1 & 3 & 6.69 & 23.92 & 47.28 & 7.79 & 1.92 \\
4 & 98.24 & 0.31 & 0.6 & 0.51 & 0.14 & 4 & 6.88 & 25.13 & 43.97 & 10.69 & 1.68 \\
8 & 93.05 & 1.62 & 3.37 & 1.55 & 0.26 & 8 & 4.37 & 36.49 & 38.35 & 14.91 & 1.13 \\
12 & 74.86 & 8.88 & 10.54 & 4.51 & 0.4 & 12 & 3 & 41.6 & 36.28 & 15.31 & 0.95 \\
\hline Fs shock (\%) & Vix & hb & spread & fs & gdp & Hb shock (\%) & Vix & hb & spread & fs & gdp \\
1 & 0 & 1.93 & 0.03 & 95.9 & 1.28 & 1 & 0 & 99.06 & 0.94 & 0 & 0 \\
2 & 3.95 & 4.97 & 0.14 & 84.22 & 4.18 & 2 & 8.35 & 87.72 & 1.1 & 0.45 & 0.09 \\
3 & 10.85 & 7.3 & 0.25 & 74.43 & 4.04 & 3 & 12.9 & 81.74 & 1.45 & 0.78 & 0.13 \\
4 & 14.13 & 8.87 & 0.42 & 68.82 & 3.88 & 4 & 15.58 & 77.44 & 1.94 & 1.1 & 0.16 \\
8 & 17.47 & 11.42 & 1.92 & 59 & 3.49 & 8 & 16.39 & 66.99 & 6.28 & 3.16 & 0.27 \\
12 & 15.46 & 16.72 & 6.36 & 50.25 & 2.98 & 12 & 12.06 & 57.98 & 15.4 & 6.77 & 0.44 \\
\hline Gdp shock (\%) & Vix & hb & spread & fs & gdp & & & & & & \\
1 & 0 & 0.8 & 0.28 & 12.65 & 85.28 & & & & & & \\
2 & 43.14 & 1.28 & 2.32 & 8.3 & 37.58 & & & & & & \\
3 & 44.39 & 2.12 & 4.18 & 9.24 & 32.97 & & & & & & \\
4 & 43.01 & 3.57 & 6.49 & 10.29 & 29.61 & & & & & &
\end{tabular}

